\title{
Raro y difícil
}

\author{
Un invierno propio (Consideraciones) \\ Luis García Montero \\ Madrid: Visor, 2011
}

\begin{abstract}
ÁNGELES MORA
El lector suele ser el primer invitado a la mesa poética de Luis García Montero, que siempre busca y provoca nuestra implicación. A veces se dirige a nosotros, sus lectores, con la complicidad de un amigo y otras nos trata de usted y nos pide por favor que le digamos la hora o nos pone en un compromiso preguntándonos cosas más serias como "qué significan/ el tú y el yo, la edad y la palabra España", como ocurre en el primer poema de Un invierno propio. Pero sin esperar la respuesta -que no le podemos dartoma la palabra por nosotros para indagar en todas esas cuestiones que verdaderamente ocupan el meollo de nuestro desconcierto. Luis García Montero se esfuerza en desentrañar para sí mismo y para los demás las preguntas que todos nos hacemos en medio del desorden interior y exterior en el que vivimos.

He aceptado su invitación y he leído este libro con la complicidad que nos propone. Para explicar algunas sensaciones de lectura diría en primer lugar que el personaje histórico que es Luis García Montero se vuelca y se transforma literariamente en ese personaje otro que, además de llamarse Luis y vivir en la calle Larra de Madrid y estar enamorado, vive en el idioma, en las palabras. Ese personaje que nos confiesa en el segundo poema de este libro que el idioma es la patria del poeta, a la vez que nos muestra cómo en las palabras pueden vivir y conviven todas las personas, cosas, sentimientos, pensamientos, toda la historia y el tiempo que lo constituyen, que son su mundo. Ese mundo que también los poemas quieren hacer nuestro, de los lectores que nos identificamos no ya con el poeta sino sobre todo con el poema y su personaje: el
\end{abstract}


que anda, habla, reflexiona, sufre, ama, sueña o pierde los sueños, encuentra el dolor o la alegría, la amistad o el frío que le transmiten sus aventuras y desventuras diarias, tan parecidas a las nuestras. De manera que todos podríamos ser ese personaje poético que se pregunta por el yo y el tú y por España: por la historia que nos hace y deshace.

Esta es la primera constatación: la poesía es una suerte de gran pregunta que los hombres y mujeres de todos los días -no sólo los poetas- hacen al mundo, a la historia. O una manera de preguntarse uno mismo por el significado y el sentido de la vida, de la historia, del tiempo, o sea, de nuestra vida histórica y temporal. Concreta. Diaria.

Luis García Montero es de los poetas que piensan que ni la poesía ni el poeta han de vivir en un mundo aparte, exquisito, pero alejado de la realidad social, de la vida diaria, de la gente que nos rodea. Piensa que si el poeta tuviera que vivir en un lugar aparte, fuera del mundo, en ese caso no valdría la pena escribir poesía, como tampoco valdría la pena hacer un teatro que no ahondara en las relaciones sociales, ni escribir novelas, ni pintar, ni ser fotógrafo. La literatura es importante y vale porque nos ayuda a explicarnos la vida, nuestra vida. Y aún tiene otra aspiración más honda y difícil: la voluntad de incidir en la transformación de lo que no nos gusta de nuestro mundo.

Los poetas que comenzaron a escribir en Granada dentro de aquel impulso -por así decirlo- que se llamó "La otra sentimentalidad" tenían muy claro que cuando volcaban su intimidad en un poema estaban vaciando también, de manera más o menos consciente, en el poema su ser social, estaban hablando de su manera de ver e interpretar el mundo. Se trataba por tanto de ser conscientes de lo que hacían a la hora de escribir poemas. Se trataba de escribir para buscar la conciencia propia y la de la sociedad, puesto que los sentimientos son históricos, como la manera de ser social.

Luis García Montero, desde aquel lejano punto de partida, ha seguido abriendo y ahondando en un camino poético muy personal y fructífero, con significativos e importantes títulos y múltiples reconocimientos, entre ellos el Premio Nacional de Literatura y el de la Crítica, hasta llegar a este su último libro: Un invierno propio.

He hablado brevísimamente del punto de partida de la poesía de Luis, de premisas y posiciones teóricas e ideológicas. Esto, con ser tan importante y tan decisivo, sin embargo no es ni mucho menos todo. Porque la hora de la verdad de un poeta se 
juega ante una página en blanco. Precisamente en un poema de este libro se dice que es preferible a veces dejar en blanco el papel... Y a la hora de la verdad, a la hora de enfrentarse al papel en blanco, al poema, Luis es un verdadero mago, sabe quedarse fuera y al mismo tiempo estar dentro de los versos. Hace que el poema piense, hable y viva como él quiere, pero al mismo tiempo es el poema el que acaba envolviéndolo y envolviéndonos con la vida que crece dentro de sus versos, de manera que su respiración nos da calor, sus imágenes luz y su lluvia nos moja. Siempre en los poemas de Luis encontramos ese doble plano, reflexivo y envolvente, que hasta en los momentos que puedan parecer más prosaicos lleva por debajo un hilo metafórico tenso, potente, rico, que es lo que provoca la emoción y la complicidad del lector.

Diría que Un invierno propio, es en un sentido amplio una continuación de su obra anterior, pero significa también un paso más hacia un discurso cada vez más desnudo, más directo, si se quiere, que cobra más fuerza, sin perder el lirismo subterráneo, por así decirlo, del que acabo de hablar. Una originalidad y un acierto espléndido es -no cabe duda y sorprendió desde sus primeras críticas- la manera de titular los poemas, que a veces se acerca a lo que Gómez de la Serna llamó greguería o a los aforismos. Incluso la disposición de los títulos, en página aparte precediendo al poema, como si fueran proposiciones que se van a desarrollar en el poema o bien que lo resumen, puesto que cada poema de este libro parece que encierra un aprendizaje moral. También llama la atención que no encontremos divisiones en partes, que no haya bloques de poemas que se reúnan por alguna circunstancia temática o literaria, o sea, esta distribución de los textos poéticos en riada, diríamos, como si no pretendiera seguir ningún orden: como la vida nos desordena, como nos desordena este invierno de las ideas y de la ética, este invierno de los valores que podrían sostener una moral laica y civil, pero que nos está dejando helados.

Es curioso que Luis García Montero no se busque un otoño sino decididamente un invierno después de su Vista cansada, a los 50 años. Pero es que al lado de esa imagen biológica, un tanto engañosa, lo que el poeta nos anota aquí es que la realidad que vivimos todos es un invierno global y subjetivo. ¿Es que el invierno actual nos ha congelado a todos? En cierto modo, sí. De ahí el preguntarse por la subjetividad de este invierno global convirtiéndolo en propio. Es decir: cuando todo se vuelve -para cada 
uno- raro y difícil, como en el último poema, al cerrar la puerta, que nos remite a la vida de adentro y afuera.

"Tal vez nos vamos de nosotros mismos, pero queda casi siempre una puerta mal cerrada". Este es el título que precede a ese último poema del libro. "Todo es raro y difícil" -dice al final- "como sentirse Luis, como vivir en el segundo/ izquierda de la noche,/ ser español o estar enamorado". Recordemos también el primer poema: "Mi nombre es Luis,/ soy español,/ vivo en Madrid,/ en el número uno, calle Larra".

Sí, es difícil escapar de nosotros mismos, siempre queda una puerta mal cerrada... Como el poeta lo sabe, nunca ha pretendido escapar de sí mismo ni escribir para evadirse de nada, sino que cogiendo al toro por los cuernos, ha convertido su yo $-\mathrm{O}$ el de cada uno de nosotros- en la materia de que están hechos sus poemas, sacándolo de sí hasta donde puede para manosearlo en los versos y hacer que sus lectores subamos y bajemos con él las escaleras de los poemas, aunque siempre nos quede la sombra de una puerta mal cerrada. Sí, raro y difícil es el nombre y el mundo, como nosotros mismos.

(Recibido: 01-06-2011; aceptado: 08-06-2011) 